\title{
Perception and Satisfaction of Ecotourism Resource Development in Gunung Ledang Johor National Legendary Park in Malaysia: Ecotourists Perspective
}

\author{
${ }^{1}$ Sabarudin bin A. Kadir Wahab, ${ }^{2}$ Dr. Mohd Rusli bin Ya'cob \\ ${ }^{1}$ Faculty of Environmental Studies, Universiti Putra Malaysia, 43400, Selangor, Malaysia \\ ${ }^{2}$ Associate Professor, Faculty of Environmental Studies, Universiti Putra Malaysia, 43400, Selangor, Malaysia \\ Correspondence Author: Dr. Mohd Rusli bin Ya'cob, Associate Professor, Faculty of Environmental Studies, Universiti Putra Malaysia, 43400, Selangor, \\ Malaysia. \\ E-mail: mroy@upm.edu.my
}

Received date: 18 May 2019, Accepted date: 6 June 2019, Online date: 29 June 2019

Copyright: () 2019 Sabarudin bin A. Kadir Wahab et al., This is an open-access article distributed under the terms of the Creative Commons Attribution License, which permits unrestricted use, distribution, and reproduction in any medium, provided the original author and source are credited.

\begin{abstract}
In conjunction with Visit Malaysia Year 2014 theme "Celebrating 1Malaysia Truly Asia" as a great platform event for promoting ecotourism sites. In 2012, Malaysia registered 25 million tourist arrives and RM60.6 billion in tourist receipt, as 10th most popular tourism destination in the world. Ecotourism as environmental consciousness that promotes conservation of natural resources. Hence, ecotourism is one of key sectors for, which is committed for utilizing ecotourism potential that helps PTNJ to manage the GLJNLP's tourism industry. The park approximately $107 \mathrm{sq} . \mathrm{km}(8,611$ hectares) has a very high concentration of ecotourists with the visitors flow on an average is 24,606 visitors yearly from the year 2011 to 2012 . The objective of the study is to determine the ecotourists perspective on attitude of ecotourism activities to fulfill their environmental knowledge needs. Ecotourists however are central stakeholder of national parks and a profound understanding of their attitudes towards protected area management is important. The study examined the ecotourists' attitude via the sociodemographic factors, the Visit Characteristic by Perception Level and factor influence the Satisfaction Level. A quantitative survey was conducted among 213 respondents by using judgmental sampling with close-ended and open-ended questionnaires. Collected data were analyzed using descriptive statistics and Multiple Regression Analysis. The findings revealed the relationship between Satisfaction Level at the GLJLNP's services/activities and Visit Characteristics by Perception Level were statistically not significant $\left(R^{2}=0.0119, P<0.05\right)$ that thirteen dependent variables explained $1.19 \%$ of the variation in independent variable. On the other hand, predictor variables of Quality Services, Natural Features, Friendliness Wellcoming, Quality Activities are greater than the common alpha level of 0.05 , which indicates that is statistically significant. A larger $p$-value $(>0.05)$ indicates that researcher can reject the null hypothesis. Because it is likely to be meaningfulness addition to the regression model fits the data because changes in the predictor's value are not related to changes in independent variable. As a conclusion, the ecotourists' satisfactions will be improved through develop their positive perceptions and travel experiences via monitoring environmental conditions in the GLNP. However, ecotourists' visit characteristic by perception are no influencing to their satisfaction.
\end{abstract}

Keywords: Ecotourism, ecotourists perspective, perception, satisfaction, Gunung Ledang Johor National Legendary Park, Perbadanan Taman Negara Johor, Multiple Regression Analysis, dependent variables, independent variables

\section{INTRODUCTION}

Ecotourism is regarded as environmental consciousness that promotes conservation of the natural resources as well as benefits the society at large that helps Perbadanan Taman Negara Johor (PTNJ) to manage the national park's tourism industry. The ultimate objective of ecotourism as a viable alternative to the conservation of forest and enhancing the standard of living of the dependent communities such as the local trekker guides and porters. Ecotourism term was coined in 1987 by Hector CeballosLascurain as traveling to undisturbed natural areas for studying, admiring, and enjoying the scenery and its wild plants and animals, as well as any existing cultural manifestations (Butler, 1991).

In 2012, Malaysia registered 25 million tourist arrivals and RM60.6 billion in tourist receipts, placing the country firmly as the 10th most popular tourism destination in the world. Malaysia will celebrate its fourth Visit Malaysia Year 2014 with the theme 
Citation: Sabarudin bin A. Kadir Wahab, et al., Perception and Satisfaction of Ecotourism Resource Development in Gunung Ledang Johor National Legendary Park in Malaysia: Ecotourists Perspective. Australian Journal of Basic and Applied Sciences, 13(6): 82-92. DOI: 10.22587/ajbas.2019.13.6.9

"Celebrating 1Malaysia Truly Asia" (Tourism Malaysia, 2013) as a great platform event for promoting ecotourism sites (DirectorGeneral of Tourism Malaysia, 2013). The Ministry of Tourism Malaysia also established ecotourism policy and guidelines as part of New Tourism Policy 2002 and National Ecotourism Plan 1997. Ecotourism is one of the key sectors for PTNJ, which is committed for utilizing ecotourism potential. Ecotourism at Gunung Ledang Johor National Legendary Park (GLJNLP) is naturebased park with high potential features for ecotourism development in the natural ecosystem. The site has a very high concentration of ecotourists. Data from the on-site visitor counters show significant increases in visitor numbers between the two years. Comparing the total registrations for comparative periods of measurement reveal a 7,126 (28.9 percent) visitors increase in visitation. Based on (PTNJ, 2011; 2012) figures, the total number of visitors is estimated at 21,043 in 2011 and 28,169 in 2012 (Table 1). The visitors flow on an average is 24,606 visitors yearly. However, success cannot be measured by the number of people who visit the operation, but consideration must be given as to the customers' levels of satisfaction and their likelihood of returning (Khairun Najiah Ahmad Zuliah Abd Hamid, 2011). Thus, the public perception and visitors can be influenced by sociodemographic factors as well as a variety of other psychology variables (Galoway, 2002). The ecotourism resource development as most important aspects in preservation and educate the ecotourists on the environmental awareness. Ecotourism resource developments also have significantly increased the need for the ecotourists to acquire knowledge on environmental awareness. In contrast, ecotourism activities effects and development impacts can have adverse environmental due to increased numbers of visitor because of the harmful physical, pollution and depletion of natural resources (WWF Malaysia, 2013).

Table 1 Visitors Arrivals at GLJNLP from the year 2011 to 2012

\begin{tabular}{|c|c|c|c|}
\hline Year & Domestic Arrivals & International Arrivals & Total Visitors \\
\hline 2012 & 26,431 & 1738 & 28,169 \\
\hline 2011 & 19,124 & 1,919 & 21,043 \\
\hline \multicolumn{4}{|c|}{ Average Visitors Flow Yearly : 24,606 } \\
\hline
\end{tabular}

Sources: PTNJ, 2011; 2012

\section{Problem Statement}

A study conducted has immense ecotourism potential, considering the number of visitors who visit the site area in different seasons and the income generated by way of entry fee. Conversely through researcher observation that the forest nature is detrimental immensely due to compromising for conservation fees collection from the ecotourists who participating in the ecotourism activities. Income from tourism could contribute significantly to the better management of the site and outweigh the negative impact of tourism which can be significantly reduced by ecologically and sustainable practices (Scott, D, and Willits, F.K.,1994). Human interactions have eroded and modified extensive forest tracks during the last century. PTNJ manager should give utmost importance to the adverse impact of the increasing pressure of the ecotourist on the biodiversity and its income generating and income dispersing capacity into the local economy. The following research questions are addressed: (i) What are the ecotourists' socio-demographic profile at the study site? (ii) What are the ecotourists' perceptions on ecotourism resource development at the study site? (iii) What are the factor influence the ecotourists' satisfaction levels towards the study site?

\section{Significance of the study}

This study attempts to fill in the knowledge gap in the literature by investigating tourists' attitudes toward the ecotourism resource development at GLJNLP. From the ecotourists' attitude perspective, levels of perception and level of satisfaction towards ecotourism activities are important due to its possible consequences on their environmental knowledge. This study would beneficial, as it will contribute in the evaluation of the ecotourism activities by PTNJ. Ecotourists' attitude in ecotourism activities has ability to find instant interpretation that can eliminate the frustrating them quickly, eliminate confusion and misinformation, and ultimately translate into more satisfied tourists. It can also translate into more a better reputation for PTNJ. The evaluation of the ecotourism activities services effectiveness is regarded as crucial in determining ecoturists' satisfaction. The results from this study also will provide a baseline data against which to measure changes in ecotourists' attitude over the short and medium terms. The information about and generated by visitors is essential to the successful planning and management of natural areas. Thus, it will awaken PTNJ manager to reevaluate the services whether it really meet the ecotourists perception or not.

\section{Objectives of this study}

Basically, the study's purpose to analyze the attitude of ectourists on the ecotourism resource development to measure the levels of perception and satisfaction where it is likely to be essential in the construction of the ecotourists' attitude. The current study examines the effectiveness of the ecotourism activities via a case study approach. The general objective of the research is to determine the ecotourists' perspective on attitude of ecotourism activities to fulfill their environmental knowledge needs. The specific objectives of the study are: - (i) to determine the ecotourists' socio-demographic profile at the study site? (ii) to determine the ecotourists' perceptions on ecotourism resource development at the study site? (iii) to determine the factor influence the ecotourists' satisfaction as a recommendation and appropriate policy for PTNJ.

\section{Literature Review}

Previous environmental attitudinal research in a tourism context has concentrated on ecotourists and their attitudes, focusing on general environmental concerns (Dolnicar, 2010). As McDougal and Munro (1994) claimed that attitude is comprised of cognitive (beliefs and knowledge), affective (feelings of like or dislike) and behavioural components (action or intent to act). Attitude causes people either like or dislike an object, and move toward or away from it (Kotler, 2001). Hence, visitors however 
Citation: Sabarudin bin A. Kadir Wahab, et al., Perception and Satisfaction of Ecotourism Resource Development in Gunung Ledang Johor National Legendary Park in Malaysia: Ecotourists Perspective. Australian Journal of Basic and Applied Sciences, 13(6): 82-92. DOI: 10.22587/ajbas.2019.13.6.9

are central stakeholder of national parks and a profound understanding of their attitudes towards protected area management is important (Galloway, 2002; Muller and Job 2009; Von Ruschkowski, 2010). Visitor attitudes to potential management actions can assist in predicting the consequences of specific actions on the ecotourist experience, and thus result in management actions that take into account both visitor satisfaction and ecological well-being (McCool et al., 1990). For that reason, several studies have analysed factors influencing the attitudes of the visitor toward national parks in Europe (Machairas and Hovardas, 2005; Muller and Job, 2009; Papageorgiou, 2001; Sterl et al., 2008; 2010). Furthermore, studies by Dowling (1993) and Ballantyne et al., (1998) also emphasized the importance of, among other things, understanding visitors' attitudes and beliefs in relation to to urism and the experience of natural area sites to aid in effective management. As regards a tourist's perception is important towards a tourist's attitude, having an effect on travel decisions (Tourism Authority of Thailand, 2010). Perception is the process of attaining awareness or understanding of sensory information of course, communication is an important aspect of changing someone's perception and attitude. Perception as the process by which an individual select, organize and interprets information inputs to create a meaningful picture of the world (Kotler, 2001). The impact of travel on tourists' attitudes and perceptions has been previously analyzed (Carlson and Widaman 1988; Crompton 1979; Gardner 1986; Pearce 1982; Pizam, Neuman and Reichel 1978; Welds and Dukes 1985). The studies investigating possible attitudinal difference among nature-based tourists suggest a need for more case studies of environmentally covering tourists' perceptions and attitudes toward specific environmental issues and management approaches, in order to better leverage attitudes for both segmenting tourist and for designing communication strategies aimed at managing tourist behaviour (Huang et al., 2008; Lai et al., 2009) as well. Based on attitudes toward environmental issues might be a good predictor of behavioral interactions and might eventually predict actual behaviour under an optimal set of conditions contingent upon attitude accessibility and subjective norms (Tanuja Singh, Michael H. Slotkin and Alexander R. Vamosi, 2007). Davis (1989) also indicated that behavioural significantly predict action. Meanwhile environmental attitude is seen as a physiological tendency characterized by the cognitive and affective evaluation of environmentally-related activities issues (Eagly \& Chaiken, 1993). Environmental attitude can be used to predict behaviour and intention someone in the environment issue (Mobley et al., 2009). Conversely previous studies (Hvenegaard and Dearden, 1988; Muller and Job, 2009) indicted that education influence protected area attitudes. Generally, the research on tourism in protected areas suggests that tourist who particularly appreciates the national park settings commonly show a more positive attitude toward nature conservation (Newsome et al., 2002; Shultis and Way, 2006).

\section{Site Description}

GLJNLP is located on north west of Johor, Malaysia and about $3 \mathrm{~km}$ from Sagil town of Ledang District (Figure 1). It is geographically located at latitude (2.3569 degrees) $2^{\circ} 21^{\prime} 24^{\prime \prime}$ North of the Equator and longitude (102.5751 degrees) 102 34 '30" East of the Prime Meridian on the Map of Malaysia. The park has been gazetted as Johor National Park (JNP) on $3^{\text {rd }}$ October 2005 with covers an area of 107 sq. km (8,611 hectares). Gunung Ledang or 'Mount Ophir' peak is the highest mountain in southern Peninsular Malaysia with 1,276 metres above sea level which Malaysia's $64^{\text {th }}$ highest mountain and the 6 th most difficult to climb. Gunung Ledang is now a living legend, as curious or serious trekkers and nature lovers continue to scale its trails to submit which offers trekking, camping or recreation. There are three trekking entry points which in Lagenda trail, Jementah trail and Asahan trail. Meanwhile for the trekkers will be charged at RM17 (Malaysian) and RM37 (foreigner) for a day trip fee (PTNJ, 2013). There also the local trekker nature guides services for RM220 per day. Ecotourists have a choice of camping in the wilderness to listen to the mystifying sounds of insects and animals. A private chalets and huts provide modern accommodation, hall and food and beverage facilities. Rest shades, picnic spots and campsites are available. Recreational seekers make day trips to enjoy the serenity, or to enjoy a relaxing splash below the waterfalls. Gunung Ledang's fame is contributed by its history as the mountain of hope for gold prospectors and its rich folklore that includes a pretty and ingenuous princess. Its enduring appeal is partly due celebrated association with the legend of the Princess of Gunung Ledang, who famously turned down a royal proposal as to preserve her independence. The locals believe the mountain to be the enchanted abode of fairies and forest spirit.

\section{MATERIAL AND METHOD}

\section{Data Collection}

The unit of analysis for this study is approximately 2,000 ecotourists who are visiting the site monthly were selected as a population perspective because of the time constraints for completion. This population is the target audiences where they will be asked to respond to the questionnaires. The sample for this study is subset or portion of the total population of ecotourists. A quantitative survey was conducted among 213 respondents by using judgmental sampling with close-ended and open-ended questionnaires. The questionnaires were distributed then collected personally and the response rate was 100 percent, meaning 213 questionnaires were collected in this study. The sampling is conducted with the intent to ensure heterogeneity among the study sample. The questionnaires were distributed directly to respective ecotourists as respondents on $3^{\text {th }}$ to $23^{\text {th }}$ October 2013 and collected on the spot. All questionnaires were returned by the respondents and representing 100 percent of the response rate. Beside the questionnaires, an interview was also conducted with the PTNJ manager and staffs including the local trekker nature guides, to get more details information on ecotourism activities. Information gathered from the questionnaires survey and interviews as the primary data were synthesized to support the current study. Meanwhile, sources from the journals, thesis and PTNJ internal documents were collected as secondary data. The questionnaires were modified to suit the current study's requirement ecotourism activities. The questionnaires structure is divided into two section comprising 9 open-ended and 9 closeended questions. The answers to all the questionnaires were treated confidential and data obtained from the results of the questionnaires have been used as evidence in findings of the current study. The first part of the questionnaires measures the psychographic pattern on the extent to which measure the ecotourists' perception level on the ecotourism resource development 
Citation: Sabarudin bin A. Kadir Wahab, et al., Perception and Satisfaction of Ecotourism Resource Development in Gunung Ledang Johor National Legendary Park in Malaysia: Ecotourists Perspective. Australian Journal of Basic and Applied Sciences, 13(6): 82-92. DOI: 10.22587/ajbas.2019.13.6.9

with the multiple answers of the open-ended and close-ended questions and any comments. Respondents also are requested to rate the ecotourists' satisfaction level based a four-point Likert type scale measurement ranging from 1=Very Satisfied, 2=Satisfied, 3=Dissatisfied and 4=Not Satisfied At All. The preference of ecotourists on the satisfaction of ecotourism resource development indicating lower value for higher preference. The second section consists of five questions pertaining to the respondents' sociodemographic information categories such as gender, age group, highest educational level, occupation and level of income.

\section{Statistical Analysis}

A total of 213 questionnaires were analyses by using the StatPlus 2007 Profesional for Windows, a AnalystSoft Inc, statistical analysis program tool software. For the interpretation of result, the Frequency Distribution Analysis on the respondents' demographic information is used. Descriptive Analysis displays the frequencies and the percentage and also the mean value as distribution of respondents of the socio-demographic factors. The frequencies procedure is useful for obtaining summaries of individual variables and distribution used to describe the profile of the sample. Multiple Regression Analysis (MRA) seeking to find an equation that describes or summarizes the relationship between more variables. This analysis aims to estimates the coefficient of the linear equation; involving more independence variables (IV) that best predict the value of the dependent variable (DV) as a function of the value of the independent variable (input variable). Its estimates the conditional expectation of the DV gives independence variable that is the average value of the DV when the IV are fixed. Also it is assumed in multiple regression that the residuals (predicted minus observed values) are distributed normally. It is predicted the factor influencing their satisfaction level on the ecotourism resource development. Thus, it also suitable to investigate the significant among the Visit Characteristics of respondents by Perception Levels (DV) are related to Satisfaction Level (IV) of GLJNLP's services/activities. The Model $\mathbf{Y}=\boldsymbol{\beta}_{\mathbf{0}}+\boldsymbol{\beta}_{\mathbf{1}} \mathbf{X}_{\mathbf{1}}+\boldsymbol{\beta}_{\mathbf{2}} \mathbf{X}_{\mathbf{2}}+\boldsymbol{\beta}_{\mathbf{3}} \mathbf{X}_{\mathbf{3}}+\boldsymbol{\beta}_{\mathbf{4}} \mathbf{X}_{\mathbf{4}}+\mathbf{\varepsilon i}$ whereas DV: Y=Ecotourists' Visit Characteristics Perception Level. IV: $\mathrm{X}=$ Ecotourists' Satisfaction Level on the GLJLNP's services/activities whereas $\mathrm{X}_{1}=$ Quality Services \& Public Accommodation; $\mathrm{X}_{2}=$ Natural Features; $\mathrm{X}_{3}=$ Friendliness Welcoming; and $\mathrm{X}_{4}=$ Quality Activities .

\section{RESULTS}

\section{Respondents' Socio-Demographic Background}

The socio-demographic profiles are comprised of the gender, age, education level, occupation and level of income of respondent's information background. A frequency procedure was computed to analyze the socio-demographic of the respondents. Table 2 shows an analysis by the 135 (63.4 percent) gender out of 213 respondents, are male ecotourists and 68 (31.9 percent) are female ecotourists. An analysis by the age's group shows most of the 120 (56.3 percent) respondents are 24 years old and below. They are 69 (32.4 percent) respondents between the ages of 25 to 40 years old. A minority of age level is only 12 (5.6 percent) respondents are 41 years old and above. In term of analysis by the respondent's highest educational level shows that (12) 5.6 percent out of 213 respondents, respondents hold a master's degree and PhD Degree. The majority of the respondents who 71 (33.3 percent) have achieved a bachelor's degree and Diploma while 65 (30.5 percent of the respondents achieved their SPM and STPM. This result is expected since environmental education is well grasped which they were exposed on educated person. Furthermore, an analysis by the level of respondents' occupation, 79 (37.1 percent) out of 213 respondents, are Private and Government Staffs. Most of the 94 (44.1 percent) respondents are the students. A minority of that is only 8 (3.8 percent) respondents are in the others. Then, an analysis by the level of income displays 42 (19.7 percent) of the respondents have been earning between RM1,000 to RM2,000 whereas 15 (7 percent) of the respondents have earned for more than RM5,000. A percentage of 9.9 percent, which consist of 21 respondents, that have been earning between RM2,100 to RM3,000 and the others for 26 (12.2 percent) respondents have earned between RM3,100 to RM5,000. These may be due to the youngest ecotourists are the students who were participating in are economical, challenging and extreme trekking.

Table 2 Frequency Distribution Analysis by Respondents' Socio-Demographic Profiles

\begin{tabular}{|c|c|c|}
\hline Variable & Frequency & Percent \\
\hline \multicolumn{3}{|l|}{ Genders } \\
\hline Female & 68 & 31.9 \\
\hline Male & 135 & 63.4 \\
\hline \multicolumn{3}{|l|}{ Age } \\
\hline$<25$ years Old & 120 & 56.3 \\
\hline 25 - 40 years Old & 69 & 32.4 \\
\hline$>40$ years Old & 12 & 5.6 \\
\hline \multicolumn{3}{|c|}{ Highest Educational Level } \\
\hline SPM/STPM & 65 & 30.5 \\
\hline Diploma/Degree & 71 & 33.3 \\
\hline Master/PhD & 12 & 5.6 \\
\hline Others & 55 & 25.8 \\
\hline \multicolumn{3}{|l|}{ Occupation } \\
\hline Self-employment & 21 & 9.9 \\
\hline $\begin{array}{l}\text { Private/Government } \\
\text { staff }\end{array}$ & 79 & 37.1 \\
\hline Student & 94 & 44.1 \\
\hline
\end{tabular}


Citation: Sabarudin bin A. Kadir Wahab, et al., Perception and Satisfaction of Ecotourism Resource Development in Gunung Ledang Johor National Legendary Park in Malaysia: Ecotourists Perspective. Australian Journal of Basic and Applied Sciences, 13(6): 82-92. DOI: 10.22587/ajbas.2019.13.6.9

\begin{tabular}{|c|c|c|}
\hline Others & 8 & 3.8 \\
\hline \multicolumn{3}{|l|}{ Level of Income } \\
\hline RM1,000 - RM2,000 & 42 & 19.7 \\
\hline RM2,100 - RM3,000 & 21 & 9.9 \\
\hline RM3,100 - RM5,000 & 26 & 12.2 \\
\hline >RM5,000 & 15 & 7.0 \\
\hline
\end{tabular}

\section{Respondents' Visit Characteristics by Perception Level}

The visit characteristics of respondents are entailed of the have ever visit site before, frequently visit site, expect to do most in site, most important aspects of ecotourism in site, main reason for visiting, considering behave in environmental awareness way, presence many tourists disturbing wildlife and natural environment, ecotourism operators damaging natural environments, have ever seen any tourist behave in an environmental unconscious way, given enough information regarding do's and don'ts by stake holders (PTNJ, tour operators, travel agencies and local peoples), ecotourism activities participated in site, and have seen local people and services providers protect the surroundings environment and ecology. A frequency procedure was computed to analyze the visit characteristic of respondents' by perception level. Table 3 shows an analysis by have ever visit the site before which shows that, 128 (60.1 percent) of the respondents are never visit the site before the survey was conducted. On the contrary, 81 (38 percent) out of 213 respondents, are agreed. Most 52 (24.4 percent) of the respondents are the second time visiting the site. There are 23 (10.8 percent) of the respondents were more than third time visiting. However, less 9 ( 4.2 percent) of the respondents frequently visit the site. The table also shows that 104 (48.8 percent) of the respondents who choose the experiencing forest ecology, remote and unspoiled nature as expectation to do most in site. On the other hand, 40 (18.8 percent) of the respondents have chosen admiring the rare fauna and flora. Meanwhile there are 39 (18.3 percent) of the respondents agreed on visiting the uncrowded destination. In addition, 10 (4.7 percent) of the respondents indicated that they chose to gain learning about wildlife. Similar to Chin et al., (2000) found that over two-thirds of visitors to Taman Negara Pahang had gone there to be close to nature (78.0 percent) whilst the most common activities at Bako National Park were hiking (76.0 percent), sightseeing (72.0 percent) and observing wildlife (66.0 percent). However, only 1 ( 0.5 percent) of the respondent answered he or she will be expected an interacting with the local residents. The table displays the ecotourism participated in by 124 (58.2 percent) of the respondents which all are related to the enjoyment of back to mother nature were very extremely most important aspect of ecotourism. Tourists are more interested in sightseeing rather than promoting environmental conservation while visiting ecotourism sites (Cheng \& Wong, 2012). There are 25 (11.7 percent) of respondents indicated that ecotourism is providing the knowledge about environment and wildlife. However, less of the respondents answered it is related to negative environmental impacts which only 12 (5.6 percent). The others 6 (2.8 percent) of the respondents think that the ecotourism may perhaps as contribution for developing the socio-economic or wellbeing to the local communities and 14 (6.6 percent) of them related to participating preservation efforts. Meanwhile 26 (12.2 percent) of the respondents indicated that they chose all the answers given. For the main reason for site visiting, the table shows that there are 120 (56.3 percent) of the respondents who choose the beautiful greenlung ecology which will be improving their environmental awareness. Meanwhile there are 62 (29.1 percent) of the respondents agreed because of cultural and legendary historical mountain with attraction uniqueness to them. On the other hand, only 8 (3.8 percent) of the respondents have chosen the wonderful resort and other facilities. In addition, 20 (9.4 percent) of the respondents indicated that they chose all the answers given. An ultra-modern concrete building serving as headquarters or lodge does not fit the image of what people expect to find in a national park, (Norman Backhaus, 2003). Domestic tourists do not look for authenticity in the first place when travelling to national parks; rather they are looking for a place for leisure activities (Cochrane, 1993). They do not look for the exotic, because for most of them tropical rainforests are a part of their experience of growing up in Malaysia (Norman Backhaus, 2003). An analysis by the ranking of the respondents' self behaviour in environmental awareness that respondents place on the ecotourism activities. From that results, all 73 (34.3 percent) of the respondents agreed that their behaviour in environmental awareness are fairly good while 19 (8.9 percent) of the respondents said that their behaviour in environmental awareness are a little. Overall, the 119 (55.9 percent) respondents have agreed that they are very much about their perception in behaviour in environmental awareness toward ecotourism activities. However, only 1 ( 0.5 percent $)$ of the respondent answered that he or she is considering not good self behaviour in environmental awareness. Enhancement of environmental knowledge and awareness could be achieved through participation in ecotourism related activities (Hughes \& Saunders, 2005). An analysis on the presence of many tourist disturbing the wildlife and natural environment in site, 152 (71.4 percent) of the respondents disagreed whereas 52 (24.4 percent) are having experienced on that disturbance matter. Most 152 (71.1 percent) of the respondents are thought that the ecotourism operators are not damaging the natural environment. On the other hand, 52 ( 24.4 percent) out of 213 respondents are agreed. An analysis on have ever seen the tourist behave in an environment way, most 104 (48.8 percent) of the respondents are disagreed. On the contrary, only 4 (1.9 percent) of the respondents are agreed. Meanwhile there are 82 (38.5 percent) of the respondents which also agreed and have ever seen other tourists were throwing plastic bag and water bottle everywhere, plucking the flowers and leaves of the plant, make noise and play loud music and others. There are 130 (61 percent) of the respondents indicated that they chose agreed that the information given of regarding do's and don'ts by stake holders (PTNJ, tour operators, travel agencies \& local peoples). Conversely, 64 (30 percent) of the respondent answered disagreed. Guidance (i.e. by travel agencies, travel books, park administrations etc.) does not always meet the expectations of the visitors (Norman Backhaus, 2003). An analysis by the ranking of ecotourism activities which the respondents have participated in site expression, most 139 (65.3 percent) of the respondents choose the climbing and hiking. Other 25 (11.7 percent) respondents came for picnic and swimming at waterfall. Meanwhile there are 15 (7 percent) of the respondents favoured on jungle trekking while 8 (3.8 percent) of the respondents chosen the camping activities. However, the ecotourism activities which less participating by the 
respondents such as insect \& bird watching of 2 ( 0.9 percent), nature photography of 4 (1.9 percent), clean-up campaign of 1 ( 0.5 percent), and environmental education of 2 ( 0.9 percent) respectively. Partaking in the recreation activities in the natural environment, it helps people to escape boredom, emotional problems and health problems in the healthy way. In addition, only 4 (6.1 percent) of the respondents have participated all of ecotourism activities in site. An analysis on have seen the local people and service providers protect the surrounding environment and ecology at site, most 95 (44.6 percent) of the respondents are considered as actived. Meanwhile there are 53 (24.9 percent) of the respondents are considered very active. On the contrary, 45 (21.1 percent) of the respondents are assumed they are less active. There are only 5 ( 2.3 percent) of the respondents supposed that they were do nothing in protecting the surrounding environment and ecology at site. According to Chin et al. (2000), results from visitor perceptions of the impacts of visitor use can be taken into consideration to identify potential indicators for monitoring environmental conditions in the National Park.

Table 3 Visit Characteristic of Respondents by Perception Level

\begin{tabular}{|c|c|c|}
\hline Dependent Variable & Number of respondents & Percent \\
\hline \multicolumn{3}{|l|}{ Ever Visit Site Before This } \\
\hline Yes & 81 & 38 \\
\hline No & 128 & 60.1 \\
\hline \multicolumn{3}{|l|}{ Frequently Visit Site } \\
\hline Second time & 52 & 24.4 \\
\hline Third time & 9 & 4.2 \\
\hline More than third time & 23 & 10.8 \\
\hline \multicolumn{3}{|l|}{ Expect to do Most in Site } \\
\hline Visiting uncrowded destination & 39 & 18.3 \\
\hline Experiencing forest ecology, remote \& unspoiled nature & 104 & 48.8 \\
\hline Learning wildlife & 10 & 4.7 \\
\hline Admiring rare fauna \& flora & 40 & 18.8 \\
\hline Interacting with local residents & 1 & 0.5 \\
\hline \multicolumn{3}{|l|}{ Most Important Aspects of Ecotourism in Site } \\
\hline Back to mother nature & 124 & 58.2 \\
\hline Provide knowledge about environment \& wildlife & 25 & 11.7 \\
\hline Reducing negative environmental impacts & 12 & 5.6 \\
\hline Contribution to socio-economic (wellbeing) to local communities & 6 & 2.8 \\
\hline Taking parts in preservation efforts & 14 & 6.6 \\
\hline All & 26 & 12.2 \\
\hline \multicolumn{3}{|l|}{ Main Reason For Visiting } \\
\hline Beautiful greenlung ecology & 120 & 56.3 \\
\hline Wonderful resort \& other facilities & 8 & 3.8 \\
\hline $\begin{array}{l}\text { Cultural \& legendary historical mountain with attraction } \\
\text { uniqueness }\end{array}$ & 62 & 29.1 \\
\hline All & 20 & 9.4 \\
\hline \multicolumn{3}{|l|}{ Considering Behave in Environmental Awareness Way } \\
\hline Very much & 119 & 55.9 \\
\hline Fairly good & 73 & 34.3 \\
\hline A little & 19 & 8.9 \\
\hline Not Good & 1 & 0.5 \\
\hline \multicolumn{3}{|l|}{ Presence Many Tourists Disturbing Wildlife \& Natural Environment } \\
\hline Yes & 68 & 31.9 \\
\hline No & 143 & 67.1 \\
\hline \multicolumn{3}{|l|}{ Ecotourism Operators Damaging Natural Environments } \\
\hline Yes & 52 & 24.4 \\
\hline No & 152 & 71.4 \\
\hline \multicolumn{3}{|l|}{ Ever Seen Any Tourist Behave in an Environmental Unconscious Way } \\
\hline Yes & 4 & 1.9 \\
\hline No & 104 & 48.8 \\
\hline \multicolumn{3}{|l|}{ If Yes, In What Way } \\
\hline Throw plastic bag \& water bottle everywhere & 56 & 26.3 \\
\hline Pluck flower \& leaves of plant & 11 & 5.2 \\
\hline Make noise \& play loud music & 13 & 6.1 \\
\hline Others & 2 & 0.9 \\
\hline
\end{tabular}


Citation: Sabarudin bin A. Kadir Wahab, et al., Perception and Satisfaction of Ecotourism Resource Development in Gunung Ledang Johor National Legendary Park in Malaysia: Ecotourists Perspective. Australian Journal of Basic and Applied Sciences, 13(6): 82-92. DOI: 10.22587/ajbas.2019.13.6.9

\begin{tabular}{|l|c|c|}
\hline Yes & 130 & 61 \\
\hline No & 64 & 30 \\
\hline Ecotourism Activities Participated In Site & \multicolumn{2}{|c|}{} \\
\hline Picnic \& swimming at waterfall & 25 & 11.7 \\
\hline Jungle trekking \& conservation walk & 15 & 7.0 \\
\hline Climbing \& hiking & 139 & 65.3 \\
\hline Camping & 8 & 3.8 \\
\hline Insect \& bird watching & 2 & 0.9 \\
\hline Nature photography & 4 & 1.9 \\
\hline Clean-up campaign & 1 & 0.5 \\
\hline Environmental education & 2 & 0.9 \\
\hline All & 4 & 6.1 \\
\hline Have Seen Local People \& Services Providers Protect The Surroundings Environment \& Ecology \\
\hline Very active & 53 & 24.9 \\
\hline Active & 95 & 44.6 \\
\hline Less active & 45 & 21.1 \\
\hline Do Nothing & 5 & 2.3 \\
\hline
\end{tabular}

\section{Frequency of Respondents by Satisfaction Level}

The satisfaction level of respondents is comprised of the quality services and public accommodation, natural features, friendliness welcoming to the visitor, and the quality of activities. Kothler (2000) defined satisfaction as a person's feeling of pleasure or disappointments resulting from comparing a product are perceived performance (or outcome) in relation to his or her expectation. A descriptive statistics was computed to analyze the extent of respondents' satisfaction level in the ecotourism activities. In Table 4 displays an analysis on the quality services and public accommodation (mean=2.31) explained that 161 (75.6 percent) of the respondents identified where out of 63 (29.6 percent) very satisfied and 98 (46 percent) satisfied as well. This can attract the ecotourists attention in participating without boredom. Almost 12 (5.6 percent) out of 213 respondents, is dissat isfied whereas 2 (0.9 percent) said that it is not satisfied at all. Furthermore, an analysis on the natural features (mean=2.14), 90 (42.3 percent) of the respondents agreed that are very satisfied while 78 (36.6 percent) of the respondents are satisfied. However, only 8 (3.8 percent) of the respondents answered that they are dissatisfied on the natural features. Effective tourism management can actually enhance the quality of the natural resources that attract tourists in the first place, resulting in a positive feedback loop (McNeely and Thorsell, 1987). Another analysis on friendliness welcoming (mean=2.234) to the visitor explained that 86 (40.4 percent) of the respondents identified that it is very satisfied. This can attract the ecotourists attention in participating without boredom and revisit in the future. Meanwhile almost 78 (36.6 percent) are satisfied but 4 (1.9 percent) out of 213 respondents, said that it is not satisfied at all on the friendliness welcoming to the visitor. However, only 3 (1.4 percent) of the respondents answered that they are dissatisfied. In term of analysis on the quality of activities (mean=2.38) showed nearly 72 (33.8 percent) of the respondents agreed that are very satisfied while 84 (39.4 percent) respondents have agreed that they are satisfied. Majority of them enjoyed the ecotourism activities. Satisfied tourists are more likely to return to the same destination, and are more willing to share their positive traveling experience with their friends and relatives (Mohammad Reza Jalil et al., 2013). However, about 6 ( 2.8 percent) of the respondents said that are dissatisfied. In addition, there are 7 (3.3 percent) out of 213 respondents said that it is not satisfied at all.

Table 4 Frequency of Respondents by Satisfaction Level

\begin{tabular}{|c|c|c|c|c|c|}
\hline \multicolumn{5}{|c|}{ Scale } & \multirow[b]{2}{*}{ Mean } \\
\hline Independent Variable & VS & $\mathbf{S}$ & D & NS & \\
\hline Quality Services \& Public Accommodation & $63(29.6 \%)$ & $98(46 \%)$ & $12(5.6 \%)$ & $2(0.9 \%)$ & 2.31 \\
\hline Natural Features & $90(42.3 \%)$ & $78(36.6 \%)$ & $8(3.8 \%)$ & - & 2.14 \\
\hline Friendliness Welcoming & $86(40.4 \%)$ & $78(36.6 \%)$ & $4(1.9 \%)$ & $3(1.4 \%)$ & 2.23 \\
\hline Quality Activities & $72(33.8 \%)$ & $84(39.4 \%)$ & $6(2.8 \%)$ & $7(3.3 \%)$ & 2.38 \\
\hline
\end{tabular}

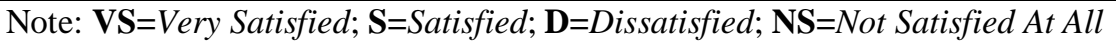

\section{Factor Influencing Respondents' Satisfaction Level by Multiple Regression Analysis}

The dummy coded variables are created that provides a means by which qualitative variable can be included in the analysis. Hence its can be used to find the best linear prediction of a criterion variable for the quality services and public accommodation, natural features, friendliness welcoming, or quality activities as the factor influencing respondents' Satisfaction Level from a set of predictor variables for the Visit Characteristics factors by Perception Level. If there is a perfect linear relationship between DV and IV, R-Square $\left(\mathrm{R}^{2}\right)$ will equal 1. Multiple Regression is equal to absolute value of the correlation between the dependent variable and predictor value. Perceived value together with past behavior and satisfaction were found to be good predictors of entertainment vacationers' intention to revisit a destination (Petrick et al., 2001). In MRA, Beta Coefficient ( $\beta$ ) is used to explain the relative important of the attribute (IV) in contributing to the variance in visitors' overall satisfaction (DV). The Table 5 provides the $R, R^{2}$, adjusted $R^{2}$, and the standard error of the estimate, which can be used to determine how well a regression model fits the data. The "R" value represents the multiple correlation coefficient. $R$ can be considered to be one measure of the 
Citation: Sabarudin bin A. Kadir Wahab, et al., Perception and Satisfaction of Ecotourism Resource Development in Gunung Ledang Johor National Legendary Park in Malaysia: Ecotourists Perspective. Australian Journal of Basic and Applied Sciences, 13(6): 82-92. DOI: 10.22587/ajbas.2019.13.6.9

quality of the prediction of the DV of Visit Characteristics. $R$ value of 0.0991 , indicates not a good level of prediction. The higher the $\mathrm{R}^{2}$, the better the model fits of the data and the weak relationship exists between the Perception and Satisfaction. The "R Square" represents the $R^{2}$ value (also called the coefficient of determination), which is the proportion of variance in the dependent variable that can be explained by the independent variables. The $\mathrm{R}^{2}$ value of 0.0119 that the IV explain $1.19 \%$ of the variability of DV, Visit Characteristics. Hence, relationship between Satisfaction Level at the GLJLNP's services/activities and Visit Characteristics by Perception Level were statistically not significant $\left(\mathrm{R}^{2}=0.0119, \mathrm{P}<0.05\right)$ that thirteen variables explained $1.19 \%$ of the variation in Satisfaction Level.

Table 5 Model Summary Table of Visit Characteristic of Perception on Influencing Respondents' Satisfaction Level

\begin{tabular}{|l|c|}
\hline \multicolumn{2}{|c|}{ Regression Statistics } \\
\hline$R$ & 0.1092 \\
\hline R-Squared & $\mathbf{0 . 0 1 1 9}$ \\
\hline Adjusted R-Squared & -0.0071 \\
\hline Standard Error & 1.6061 \\
\hline Total Number of Cases & 213 \\
\hline
\end{tabular}

a. Predictors: (Constant), Quality Services, Natural Features, Friendliness Wellcoming, Quality Activities

Coefficients indicate how much the DV varies with an IV when all other IV are held constant. Coefficient $\left(\beta_{1}\right)$ for $Q U A L I T Y$ SERVICES is equal to 0.0391 in the Table 6. This means that for each increase in QUALITY SERVICES, there is a increase in VISIT CHARACTERISTIC of 2.9701. The results have indicated that all the four factors remained significant in the regression analysis with different values of the beta coefficients, and that indicates the contributing the different weights to the variance of tourists' overall perception. Although the intercept, $\beta_{0}$, is tested for statistical significance, this is rarely an important or interesting finding. It suggests that the multiple regression model as reasonable and significant Coefficients of multiple regression analysis results showed the high correlation between the variable. Beta coefficients ( $\beta_{1}$ to $\beta_{4}$ ) of the model explained the relative important of the four, GLJNLP's services/activities related in influencing the tourists' overall satisfaction about the GLJNLP. The findings revealed there are the IV which the factors influencing respondents' satisfaction level from a set of predictor variables via the best linear prediction of a criterion variable. For the reason, there are IV have significance value $\mathrm{p}<0.05$ that shows that each model predictor is significant.

Table 6 Coefficients Table of Visit Characteristic of Perception on Influencing Respondents' Satisfaction

\begin{tabular}{|l|c|l|c|c|}
\hline & Coefficient & Standard Error & T Stat & P-Value Sig. \\
\hline Intercept & 2.931 & & & $\mathbf{0 . 6 4 3 4}$ \\
\hline Quality Services & $\mathbf{0 . 0 3 9 1}$ & 0.1041 & 0.3752 & $\mathbf{0 . 9 6 6 9}$ \\
\hline Natural Features & $\mathbf{- 0 . 0 2 5 9}$ & 0.1028 & -0.2515 & $\mathbf{0 . 9 9 2 6}$ \\
\hline Friendliness Well coming & $\mathbf{- 0 . 0 9 3 4}$ & 0.1074 & -0.8694 & $\mathbf{0 . 5 5 5 2}$ \\
\hline Quality Activities & $\mathbf{- 0 . 0 3 6 3}$ & 0.1082 & -0.3351 & $\mathbf{0 . 9 7 8 1}$ \\
\hline
\end{tabular}

a. Dependent Variable: Visit Characteristics

These variables statistically significantly predicted VISIT CHARACTERISTIC $=2.8145, p<0.6434, R^{2}=0.0119$. Predictor variables of Quality Services, Natural Features, Friendliness Wellcoming, Quality Activities are greater than the common alpha level of 0.05 , which indicates that is statistically significant. A larger p-value $(>0.05)$ indicates that researcher can reject the null hypothesis. Because it is likely to be meaningfulness addition to the regression model fits the data because changes in the predictor's value are not related to changes in DV. An estimated model coefficients, the general form of the equation to predict Visit Characteristics from IV is: Predicted Visit Characteristic $=2.931+(0.0391 *$ Quality Services $)+(-0.0259 *$ Natural Features $)+(-0.0934 *$ Friendliness Well coming $)+(-0.0363 *$ Quality Activities $)$

\section{DISCUSSION}

Since ecotourism activities have been boosting up at site area in line with the goals of PJNP Strategic Plan 2012-2016, the results will also provide baseline information against which to measure changes in ecotourists' attitudes over the short and medium terms. Thus, it could help PTNJ to realize and be more aware of the significance of ecotourist's perception and satisfaction need to integrate into PJNP's strategic plan. The results from the study may be varying due to different environmental knowledge background from the demographic factors. The study also reveals that ecotourists are different in their tastes and preferences. Understanding this information will help PTNJ to create an efficient park management, and thus will make a contribution to the long-term sustainable development of ecotourism areas. PTNJ should undertake the efforts to obtain information about tourist's expectation. Therefore, understanding the motives of the tourists in relation to their attitude change, and further adaptation of desirable behaviours through their visit to ecotourism sites would assist resource managers, ecotourism operators, local residents, and policy makers to develop a comprehensive ecotourism plan (Mingming Cheng, Xin Jin \& IpKin Anthony Wong, 2013). Researcher obtained feedbacks and suggestions from the visitors on whether PTNJ have met the needs of the ecotourists in different aspects and how it promotes ecotourism. Conversely, PTNJ has inadequate interpretive media for environmental education such as trained guides, an interpretation centre, appropriate signage, and publicity material. 
Citation: Sabarudin bin A. Kadir Wahab, et al., Perception and Satisfaction of Ecotourism Resource Development in Gunung Ledang Johor National Legendary Park in Malaysia: Ecotourists Perspective. Australian Journal of Basic and Applied Sciences, 13(6): 82-92. DOI: 10.22587/ajbas.2019.13.6.9

As a recommendation, research could be conducted which involves all the ecotourists. This will make more accurate in finding the answers. In comparing these, it needs most ecotourists to be interviewed in getting their answers and responses. The ecotourism activities are meaningful if it is being participating and explored by ecotourists. The ability to grasp environmental awareness and education should be challenging for ecotourists to acquire new environmental skill and knowledge. PTNJ should provide an advance environmental knowledge to enhance the ecotourists's skills to improve environmental awareness and education, also to meet the PJNP objective. The establishment of an education centre on-site would improve satisfaction with the visit, and thus better promote a conservation message (Chunyu Liu, Wen Xiao, Junsheng Li, Peter Pechacek, 2013). PTNJ should start carrying out certain move to address these gaps via stricter enforcement of regulations, increasing the frequency of patrol around, increasing the number of staffs on duty, putting up more board sign on do's and don'ts, designing zones for various recreational activities. It is also suggested that PTNJ assess the possible environmental degradation and carrying capacity to control the number of tourists enjoying the ecotourism activities. PTNJ needs to establish a program for monitoring and reviewing the successes or failures of the recreational activities to ensure the least damage to the natural environment and local communities surrounding the park. Ecotourism is an activity carried on within a set of social and physical conditions that are heavily influenced by government decision making (Parker, 2001). Indeed, visitors to bring back not only beautiful photos and souvenirs of the park, but as well, memorable, unique and priceless authentic experiences. This study also recommends further research to incorporate other moderating variables such as the legal and regularity environment. A participatory approach to the development of ecotourism in the site will ensure both economic and environmental security.

\section{CONCLUSION}

The ecotourism resource development from the ecotourists' attitudes in GLJNP has significantly increased the need for the ecotourists to acquire knowledge on environmental awareness. PTNJ need to establish a program for monitoring and reviewing the success or failure of the recreational activities to ensure the least damage to the natural environment and local community surrounding the park due to the lacking in the exposure of environmental knowledge by the ecotourists themselves. If PTNJ improves the quality of services and activities at the GLNP, the ecotourists will lead them towards the destination loyalty. The ecotourists' satisfactions will be improved through develop their positive perceptions and travel experiences via monitoring environmental conditions in the GLNP. However, ecotourists' visit characteristic by perception are no influencing to their satisfaction.

\section{ACKNOWLEDGEMENTS}

I wish to place on record my sincere thanks to Associate Professor Dr. Mohd Rusli bin Ya'cob, my Research Supervisor for his kind support and encouragement throughout the study period and in the field. I am thankful to Gunung Ledang Johor National Legendary Park Manager and staffs who have provided all necessary help and support in the field during the progress of the study. Special thanks are extended to the MASPUTRA Research Coordinator for his help.

\section{REFERENCES}

Abraham Pizam et al. 1978. Dimensions of tourist satisfaction with a destination area. Annals of Tourism Research, 5(3):314-322. Retrieved from https://doi.org/10.1016/0160-7383(78)90115-9 on 14 May 2019.

Ballantyne et al. 1998. Targeted interpretation: Exploring relationships among visitors' motivations, activities, attitudes, information needs and preferences. Journal. Tourism Studies. 9(2):14-25.

Buletin 1Motour. 2013. Kementerian Pelancongan, Seni dan Budaya Malaysia. Retrieved from http://www.motac.gov.my on 14 May 2019.

Butler, Richard W. 1991. Tourism, Environment, and Sustainable Development. Environmental Conservation, 18(3):201-209. DOI: $10.1017 /$ S0376892900022104.

Carlson, J and Widaman, K. 1988. Petrick, J. et al. 2001. The Effects of Study Abroad During College On Attitudes Toward Other Cultures. International Journal of Intercultural Relations, 12(1):1-17. DOI: 10.1016/0147-1767(88)90003-X.

Chunyu Liu et al. 2013. Attitude of tourists visiting nature reserves in China. Retrieved from https://doi.org/10.1016/j.tmp.2012.09.003 on 14 May 2019.

C.L.M, Chin et al. 2000. Ecotourism in Bako Nastional Park, Borneo: Visitors' Perspectives on Environmental Impacts and their Management. Journal of Sustainable Tourism, 8(1):34-42.

Cochrane, J. 1993. Gunung Leuser National Park Ecotourism Survey, report for Leuser Development Programme. Medan, Indonesia.

Crompton, J.L. 1979. An assessment of the image of Mexico as a vacation destination and the influence of geographical location upon that image. Journal of Travel Research, 17(4):18-24.

Data Ketibaan Pelawat Taman Negara Lagenda Gunung Ledang. 2011. Perbadanan Taman Negara Johor.

Data Ketibaan Pelawat Taman Negara Lagenda Gunung Ledang. 2012. Perbadanan Taman Negara Johor.

Davis, F. 1989. Perceived Usefulness, perceived ease of use, and user acceptance of information technology. MIS Quarterly, 13:318-341.

Dolnicar, S. 2010. Identifying tourists with smaller environmental footprints. Journal of Sustainable Tourism, 717-734. Retrieved from https://doi.org/10.1080/09669581003668516 on 14 May 2019. 
Citation: Sabarudin bin A. Kadir Wahab, et al., Perception and Satisfaction of Ecotourism Resource Development in Gunung Ledang Johor National Legendary Park in Malaysia: Ecotourists Perspective. Australian Journal of Basic and Applied Sciences, 13(6): 82-92. DOI: 10.22587/ajbas.2019.13.6.9

Dowling, R.K. 1993. Tourism Planning, People and the Environment in Western Australia. Journal of Travel Research, 31(4):5258. Retrieved from https://doi.org/10.1177/004728759303100408 on 14 May 2019.

Eagles, P. and McCool, S.F., 2002. Tourism in National Parks and Protected Area - Planning and Management. CABI Publishing, New York.

Eagly, A. H. and Chaiken, S. 1993. The psychology of attitudes. Harcourt Brace Jovanovich. Management and Organizations and Sociology PhD Program.

Galloway, G., 2002. Psychographic segmentation of park visitor markets: evidence for the utility of sensation seeking. Tourism Manage. 23:581-596.

Huang, S. and Hsu, C.H.C. 2009. Effects of Travel Motivation, Past Experience, Perceived Constraint, and Attitude on Revisit Intention. Retrieved from https://doi.org/10.1177/0047287508328793 on 14 May 2019.

Hvenegaard, G.T. and Dearden, P. (1998). Ecotourism Versus Tourism in a Thai National Park. Annals of Tourism Research, 25(3): 700-720.

Conservation, Ecological Integrity and Tourism Management, Journal of Sustainable Tourism, 14(3):223-237. DOI: $10.1080 / 09669580608669056$

John D. Shultis \& Paul A. Way. 2006. Changing Conceptions of Protected Areas and Conservation: Linking.

Johor National Park Strategic Plan 2012-2016. 2012. Perbadanan Taman Negara Johor.

Khairun Najiah Ahmad Zuliah Abd Hamid. 2011. Customer Loyalty To Ecotourism Destination In Ensuring Repeat Tourist: A Case Of Endau Rompin National Park (ERNP), Malaysia. Research Management Institute (RMI), Universiti Teknologi MARA Shah Alam.

Kotler, P. 2000. Marketing Management. 10th ed. New Jersey, Prentice Hall.

Machairas, I., Hovardas, T., 2005. Determining visitors' dispositions towards the designation of a Greek National Park. Environment Management, 36 (1)73-88.

Malaysia's New Ecotourism Hub Is Hornbill Capital Of The World. Retrieved from https://www.tourism.gov.my/media/view/malaysia-s-new-ecotourism-hub-is-hornbill-capital-of-the-world on 14 May 2019.

Malaysia Tourism Promotion Board. Retrieved from http://www.tourismmalaysia.gov.my on 14 May 2019.

McCool, S. F. and Martin, S. R. 1994. Community Attachment and Attitudes toward Tourism Development. Journal of Travel Research, 32(3):29-34. Resident's attitudes towards the impacts of tourism. Retrieved from https://www.researchgate.net/publication/268215662_Resident's_attitudes_towards_the_impacts_of_tourism on 14 May 2019.

McCool, S.F. and Lime, D.W. 1988. Attitudes of visitors toward outdoor recreation management policy in A.H. Watson (ed.). Outdoor Recreation Benchmark 1988: Proceedings of the National Outdoor Recreation Forum (pp. 401-411). Ashville: USDA, Forest Service.

McDougall, G. and Munro, H. 1994. Scaling and attitude measurement in travel and tourism research in B. Ritchie and C.R. Goeldner (eds.). Travel, tourism and hospitality research: a handbook for managers and researchers, 115-129. New York. John Wiley and Sons, Inc.

McNeely, J.A. and Thorsell, J. 1987. Guidelines for Development of Terrestrial and Marine National Parks for Tourism and Travel, IUCN, Gland, Switzerland.

Mingming Cheng, Xin Jin \& IpKin Anthony Wong. 2014. Ecotourism site in relation to tourist attitude and further behavioural changes. Current Issues in Tourism, 17(4):303-311. DOI: 10.1080/13683500.2013.800030.

Mohammad Reza Jalil et al. 2013. Electronic Word of Mouth Effects on Tourists' Attitudes Toward Islamic Destinations and Travel Intention: An Empirical Study in Iran. Procedia - Social and Behavioral Sciences 81:484-489. DOI: $10.1016 /$ j.sbspro.2013.06.465.

Newsome, D. et al. 2002. Natural area tourism: ecology, impacts, and management. Channel View Publications, Clevedon.

Muller, M. and Job, H. 2009. Managing natural disturbance in protected areas: tourists' attitudes towards the bark beetle in a German national park. Biological Conservation, 142:375-383. DOI: 10.1016/j.biocon.2008.10.037.

Norman Backhaus 2003. 'Non-place jungle': The construction of authenticity in National parks of Malaysia, Indonesia and the Malay World, 31(89):151-160, DOI: 10.1080/13639810304438.

Papageorgiou, K., 2001. A combined park management framework based on regulatory and behavioral strategies: use of visitors' knowledge to assess electiveness. Environment Management. 28 (1):61-73.

Parker, S. 2001. The Place of Ecotourism in Public Policy and Planning. The Encyclopedia of Ecotourism CABI Publishing. ISBN 0-85199-368-0.

Pearce, P.L. 1987. Psychological Studies of Tourists Behaviour and Experience. Australian Journal of Psychology, 39(2). Retrieved from https://doi.org/10.1080/00049538708259046 on 14 May 2019.

Petrick, J. et al. 2001. An Examination of the Determinants of Entertainment Vacationers' Intentions to Revisit. Journal of Travel Research, 40(1):41-48. DOI: 10.1177/004728750104000106.

Roland, E. and Galloway, D. 2002. Classroom influences on bullying. Educational Research, 44(3):299-312.

Soctt, D and Willits, F.K. 1994. Environmental Attitudes and Behavior: A Pennsylvania Survey Article in Environment and Behavior, 26(2):239-260. DOI: 10.1177/001391659402600206.

Sterl, P., et al. 2008. Visitors' awareness and assessment of recreational disturbance of wildlife in the Donau-Auen National Park. Journal Nature Conservation. 16, 135-145.

Tanuja Singh et al. 2007. Attitude towards ecotourism and environmental advocacy: Profiling the dimensions of sustainability. Retrieved from https://doi.org/10.1177/1356766707074736 on 13 May 2019.

Tourism Authority of Thailand. 2008. TAT lowers tourist arrival target. Retrieved from http://www.phuketclassifieds.net/index.php?a=2\&b=1408 on 13 May 2019. 
Tourism Malaysia. Retrieved from https://www.tourism.gov.my/media/view/malaysia-s-new-ecotourism-hub-is-hornbill-capitalof-the-world on 13 May 2019.

Von Ruschkowski, E. 2010. Ursachen und Lösungsansätze für Akzeptanzprobleme von Großschutzgebieten am Beispiel von zwei Fallstudien im Nationalpark Harz und im Yosemite National Park [Causes and Potential Solutions for Conflicts Between Protected Areas and Local Communities]. Hannover and Stuttgart: ibidem-Verlag.

Welds, K. and Dukes, R. 1985. Dimensions of personal change, coping styles and self-actualisation in a shipboard university. Annals of Tourism Research, 12:113-119.

W. K. Athula Gnanapala. 2015. Tourists Perception and Satisfaction: Implications for Destination Management. American Journal of Marketing Research, 1:7-19.

WWF. Malaysia Setiu Wetlands. 2013. A Perfect Choice to be Terengganu's First State Park. Retrieved from http://www.wwf.org.my/?16000/setiu-wetlands-a-perfect-choice-to-be-terengganus-first-state-park on 13 May 2019. 